\title{
SAKRAL (SISTEM KENDALI PERALATAN LISTRIK) PADA RUMAH TINGGAL BERBASIS TEKNOLOGI ANDROID
}

\author{
Ridwan Hidayatullah ${ }^{1}$, Sigit Yatmono ${ }^{2}$, \\ ${ }^{1}$ Jurusan Pendidikan Teknik Elektro FT UNY; ${ }^{2}$ Jurusan Pendidikan Teknik Elektro FT UNY \\ Email: ghoorydwan@gmail.com
}

\begin{abstract}
The purpose of this tool is to make the control system of electrical equipment in residences with Android technology. Control of electrical equipment made using a microcontroller Arduino Pro Mini that is communicated via Bluetooth media. The software is also made to be used for the applications installed on the Android smartphone. Then the output of the Arduino Pro Mini is connected to the relay module next to the load. The method used in this final project is methods of design, which consists of several stages, namely: (1) Identification of needs, (2) Analysis of needs, (3) The design of hardware and software, (4) Production of tools, and (5) Testing tools. The hardware consists of: (1) Arduino Pro Mini as the main controller in the series, (2) Bluetooth as a communication media of data, and (3) Circuit relay module. Based on the test results, it can be concluded that the control system of electrical equipment in residences works in accordance with its function. It is also very efficient because it can save time to control electrical equipment from a distance of 24 meters radius. This tool uses the relay and can be arranged with a timer contained in the application for the security of these series so that the level of resistance of electrical equipment can be maintained.
\end{abstract}

Keyword: Android smartphone, control system of electrical equipment, residences

\begin{abstract}
ABSTRAK
Tujuan pembuatan alat ini adalah membuat sistem kendali peralatan listrik pada rumah tinggal dengan teknologi Android. Kendali peralatan listrik dibuat menggunakan mikrokontroler Arduino Pro Mini yang di komunikasikan melalui media Bluetooth. Pembuatan software juga dilakukan untuk aplikasi yang diinstal pada smartphone Android. Keluaran dari Arduino Pro Mini kemudian dihubungkan ke modul relay yang selanjutnya ke beban. Metode yang dipergunakan dalam proyek akhir ini adalah dengan metode rancang bangun yang terdiri dari beberapa tahapan, yaitu: (1) Identifikasi kebutuhan, (2) Analisis kebutuhan, (3) Perancangan perangkat keras dan perangkat lunak, (4) Pembuatan alat, dan (5) Pengujian alat. Perangkat keras terdiri dari: (1) Arduino Pro Mini sebagai pengendali utama dalam rangkaian, (2) Bluetooth sebagai media komunikasi data, dan (3) Rangkaian modul relay. Berdasarkan hasil pengujian dapat disimpulkan bahwa sistem kendali peralatan listrik pada rumah tinggal bekerja sesuai dengan fungsinya. Selain itu, alat ini juga sangat efisien karena dapat menghemat waktu untuk pengendalian peralatan listrik dari jarak radius 24 meter. Alat ini menggunakan relay dan dapat diatur dengan pewaktu yang terdapat pada aplikasi untuk keamanan rangkaian sehingga tingkat ketahanan peralatan listrik dapat terjaga dengan baik.
\end{abstract}

Kata kunci : smartphone Android, sistem kendali peralatan listrik, rumah tinggal

\section{PENDAHULUAN}

Terjadinya kebakaran pada rumah tinggal umumnya dipengaruhi oleh hubung singkat atau korsleting listrik. Pemakaian peralatan listrik yang terlalu lama beroperasi juga dapat menyebabkan kemampuan lapisan pelindung kabel menurun. Arus pada beban yang terlalu lama, juga bisa mengurangi umur peralatan listrik tersebut. Sehingga peralatan listrik pada rumah tinggal cepat rusak, sebagian besar terjadi karena lupa atau malas untuk mematikan kembali peralatan listrik pada rumah tinggal. Penelitian ini menghasilkan alat tepat guna yang mudah dioperasikan sebagai solusi dan inovasi diberikan serta kontribusi nyata dalam bidang teknologi.

Dipilihnya penggunaan teknologi Android karena melihat semakin cepatnya pertumbuhan smartphone dalam dunia teknologi menciptakan suatu terobosan baru pada smartphone Android. Dominasi Android di pasar ponsel pintar dunia semakin menguat. Perangkat berbasis sistem operasi besutan 
Google itu tercatat meraih $64,2 \%$ penjualan smartphone dipasar global. Angka tersebut merupakan data penjualan perangkat smartphone pada kuartal awal 2013 oleh World Panel Comtech (WPC) (kantarworldpanel.com). Lembaga riset pasar ini melakukan penelitian di seluruh pasar utama penjualan smartphone selama 12 minggu yang berakhir pada 31 Maret 2013. Terdapat 9 negara yang disurvei oleh WPC. Data WPC menunjukkan Android mendominasi penjualan perangkat komunikasi canggih tersebut yaitu sekitar 64,2\% mengalahkan platform mobile lainnya.

Jepang jadi satu-satunya pasar di mana Android dikalahkan Apple iOS dengan penjualan masing-masing platform $45,8 \%$ dan $49,2 \%$ untuk tiga bulan terakhir yang berakhir pada 31 Maret 2013. Namun, di negara lainnya, platform berlogo robot hijau itu rerata menguasai sekitar $60 \%$ hingga $80 \%$ pasar di tiap negara (bisnis-kti.com). Alat ini dapat bermanfaat untuk menciptakan suatu rumah tinggal masa depan yang nyaman, aman, dan mempermudahkan dalam pengoperasian peralatan listrik dari berbagai tempat. Selain itu, alat ini juga dapat melakukan pengendalian pemakaian energi listrik secara hemat.

\section{METODE}

Metode dalam penelitian ini dibagi menjadi beberapa tahapan, Diantaranya adalah sebagai berikut:

\section{Identifikasi Kebutuhan}

Proses realisasi perancangan SAKRAL (Sistem Kendali Peralatan Listrik) pada Rumah Tingal Berbasis Teknologi Android perlu dilakukan identifikasi kebutuhan sistem. Tujuan identifikasi dilakukan untuk mengetahui sistem kendali saat bekerja, maka harus memerhatikan kebutuhan :

1. Arduino dan bluetooth yang akan digunakan

2. Pemakaian menu button dan seekbar pada smartphone

3. Pemrograman yang dapat menghasilkan input dan output yang sesuai.

\section{Analisis Kebutuhan Sistem}

Dalam pembuatan SAKRAL (Sistem Kendali Peralatan Listrik) pada Rumah Tingal Berbasis Teknologi Android ini perlu menganalisa kebutuhan alat dan bahan yang diperlukan, antara lain:

1. Aplikasi Android sebagai pengendali

2. Mikrokontroler Arduino dan Bluetooth sebagai media pengendali

3. Instalasi modul relay

4. Box sebagai tempat media pengendali

\section{Konsep Rancangan Alat}

Perencanaan merupakan suatu hal yang dilakukan untuk mempermudah proses pembuatan alat. Konsep rancangan SAKRAL (Sistem Kendali Peralatan Listrik) pada Rumah Tingal Berbasis Teknologi Android ini digambarkan pada diagram blok yang digambarkan seperti dibawah ini. Blok diagram menjelaskan gambaran umum memgenai cara kerja dari sistem kendali peralatan rumah tinggal yang akan dibuat.

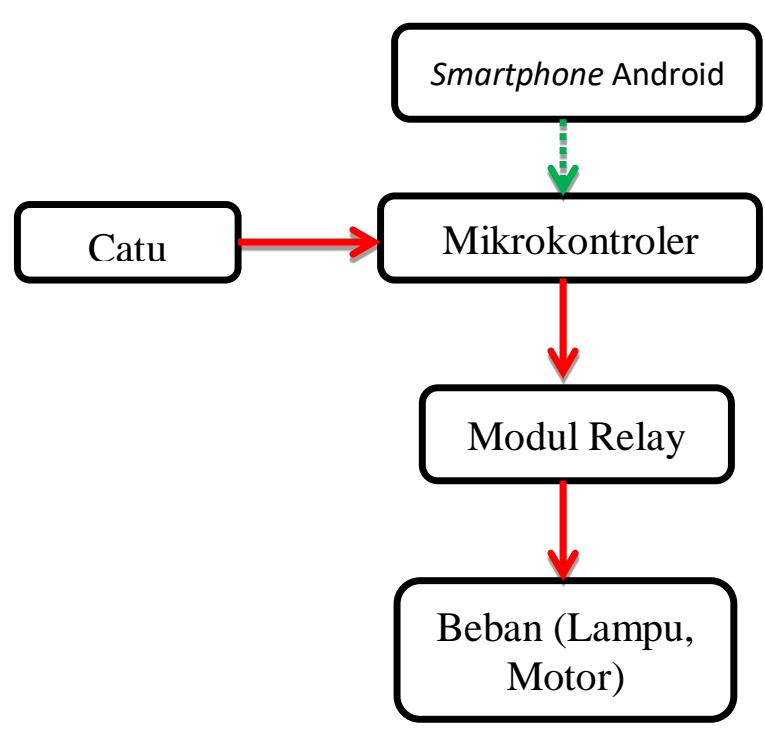

Gambar 1. Diagram Blok Rancangan Alat

Keterangan :

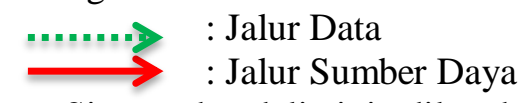

Sistem kendali ini dilengkapi dengan bluetooth sebagai media transfer data dari smartphone Android menuju mikrokontroler 
yang kemudian mengendalikan peralatan listrik. Sebelum menuju peralatan listrik, daya akan melewati relay pengaman terlebih dahulu. Tujuan dari penggunaan relay sebagai pengaman dari peralatan listrik yang akan dikendalikan.

\section{Catu daya}

Sumber tegangan yang digunakan adalah 220V AC, maka diperlukan dioda bridge untuk penyearah tegangan. Karena daya yang dibutuhkan untuk mikrokontroler hanya 5VDC maka disini menggunakan catu daya rangkaian adaptor charger.

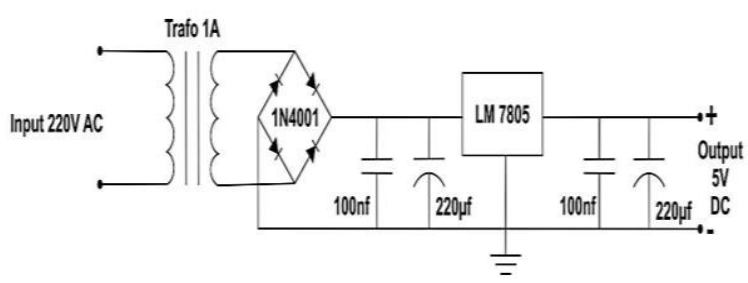

Gambar 2. Rangkaian Catu Daya

Modul Arduino Pro Mini dan Bluetooth merupakan Modul yang terdiri atas Arduino Promini yang dipadukan dengan bluetooth.

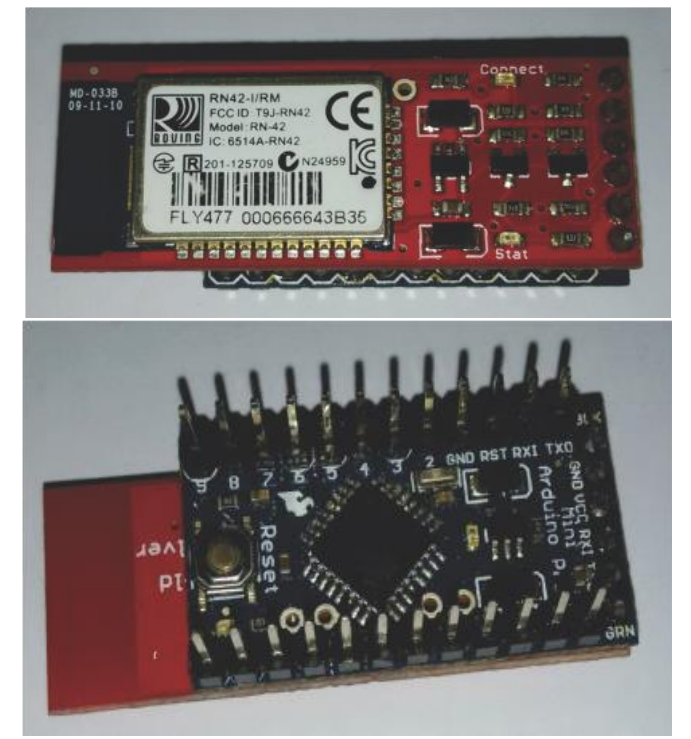

Gambar 3. Arduino Promini dengan Bluetooth
Pin yang digunakan pada Arduino yaitu :

a. Pin 6, 7, 8, 9 sebagai keluaran pengendalian tegangan $\mathrm{AC}$

b. Pin 10 dan 11 sebagai keluaran pengendalian tegangan DC

c. Pin RAW dan GND untuk dihubungkan ke sumber tegangan

d. Pin GND dan VCC untuk dihubungkan ke modul relay

\section{Modul Empat Relay}

Keluaran dari modul Arduino Promini menggunakan modul 4 relay dengan spesifikasi input 5V DC, output $250 \mathrm{~V} \mathrm{AC,} 10 \mathrm{~A}$

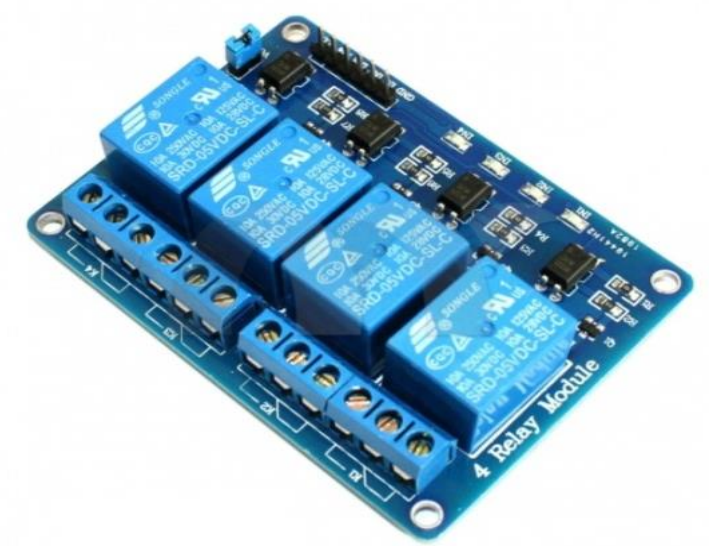

Gambar 4. Modul 4 relay

\section{Perakitan Komponen}

Pada tahap perakitan komponen dilakukan dengan menyambungkan kabel antara komponen catu daya, arduino, bluetooth dan modul empat relay. Komponen harus sesuai dengan desain yang telah ditentukan sebelumnya. Kemudian pasang kabel di soket yang sudah disediakan dan apabila tidak tersedia soket maka solder sambungan kabel supaya tersambung. 


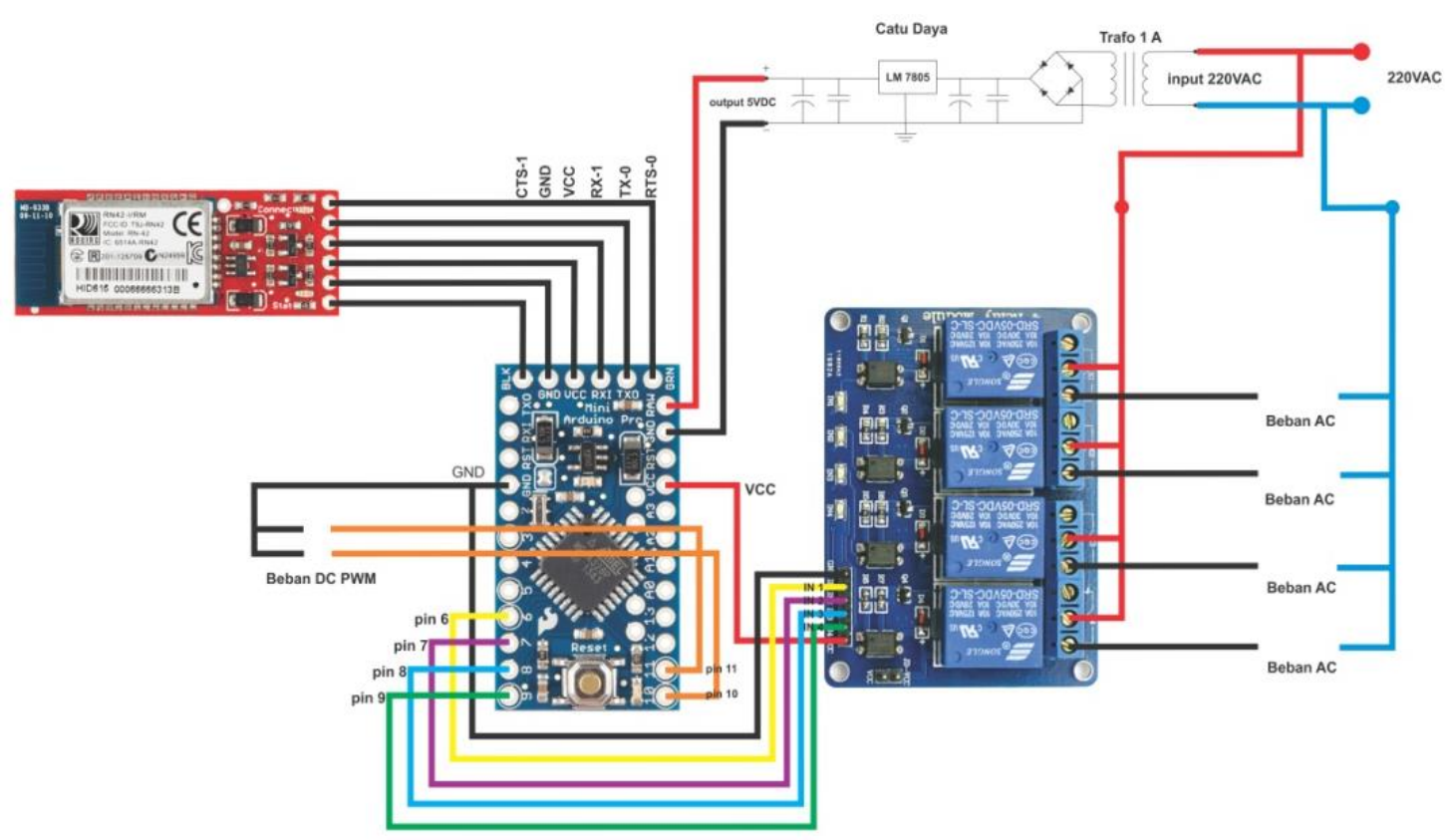

Gambar 5. Rangkaian Instalasi Antar Komponen

\section{Perancangan Software}

1. Perancangan Aplikasi pada Android

Perancangan software menggunakan program eclipse untuk program aplikasi tampilan di smartphone Android. Pemrograman dilakukan untuk membuat tampilan awal yang berupa pilihan kontrol dan on off dari pengendalian sampai dengan pengaturan pewaktu.
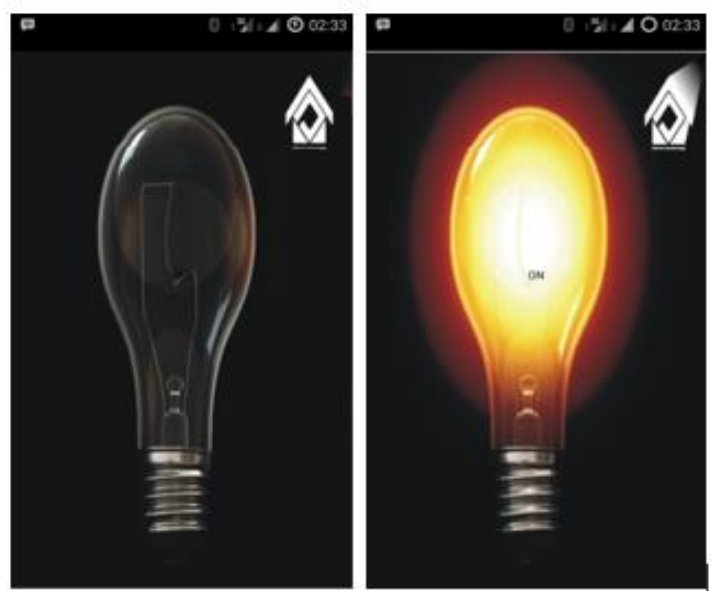

Gambar 6. Tampilan Button off dan On

Pemrograman tampilan dilakukan untuk memberi tampilan antar muka pada aplikasi kontrol yang terdapat pada smartphone Android. Berikut program tampilan yang ada pada aplikasi:
$<$ ?xml version="1.0" encoding="utf-8"?>

$<$ LinearLayoutxmlns:android="http://schemas. android.com/apk/res/android" android:layout_width="match_parent" android:layout_height="match_parent" android:orientation="vertical" >

$<$ TextView

android:layout_height="wrap_contt" android:text="Travis is..."

android:textAppearance="?android:attr/ textAppearanceSmall"

android:layout_gravity="center" android:layout_width="wrap_content" android:id="@+id/textVie1" $></$ TextVi

$>$

\section{$<$ ToggleButton}

android:id="@+id/control1" android:layout_width="fill_parent" android:layout_height="fill_parent" android:layout_gravity="center" android:paddingBottom="100dp" android:background="@ drawable/list_ btn" />

$</$ LinearLayout $>$

Pada tampilan awal Aplikasi terdapat tampilan Control_1sampai Control_4, yang memudahkan pengguna untuk memilih kontrol mana yang akan digunakan. Berikut program pada Control_1 : 


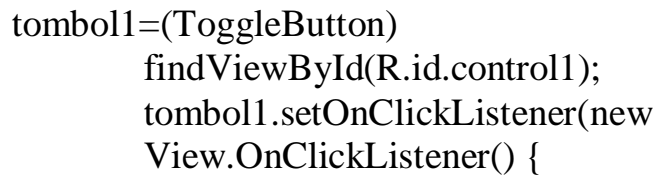

@ Override public void onClick(View v) \{

// TODO Auto-generated method stub

if(tombol1.isChecked ()$)\{$ aman1 $=0 ;\}$ else \{

aman $1=255$;

updateRed();

$$
\text { \} }
$$

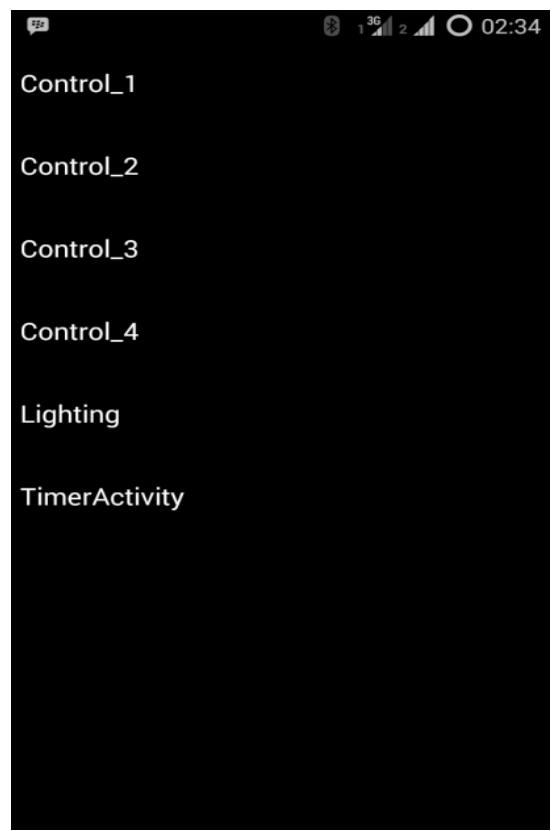

Gambar 7. Tampilan Awal Setelah Masuk Aplikasi

\section{HASIL DAN PEMBAHASAN}

\section{Pengujian Tampilan Aplikasi pada Android}

Pengujian dilakukan dengan cara menjalankan aplikasi, apakah menu pada aplikasi berfungsi dengan baik atau masih terdapat kesalahan.

1. Tampilan pada smartphone Android

Tahap awal pengujian dilakukan dengan menguji tampilan aplikasi pada smartphone Android. Aplikasi dibuat dengan gambar ikon karena untuk lebih memudahkan pengguna dalam menjalankan aplikasi SAKRAL di smartphone Android.

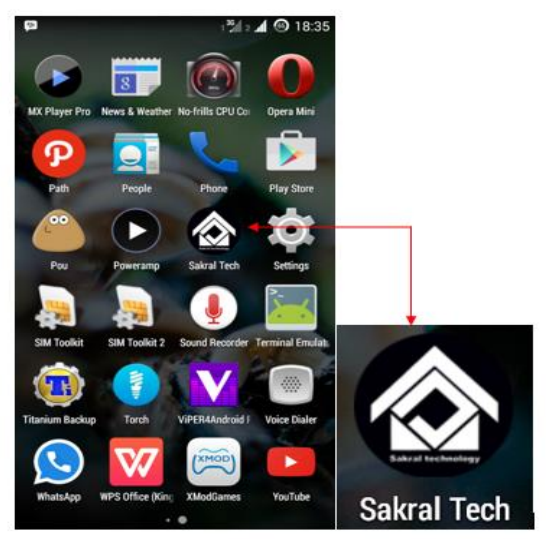

Gambar 8. Ikon Aplikasi pada smartphone Android

Gambar di atas menunjukkan letak ikon aplikasi yang ditunjuk dengan tanda panah. Ikon tersebut dirancang dengan gambar yang sesuai dengan aplikasi yang akan dibuat.

2. Tampilan menu utama pada aplikasi

Setelah tampilan booting maka aplikasi akan masuk pada tampilan menu utama yang berisikan tulisan Control_1, Control_2, Control_3, Control_4, Lighting dan Timer Activity. Tulisan pada menu utama tersebut merupakan inputan dari smartphone android yang selanjutnya akan diteruskan ke bluetooth dan mikrokontroler.

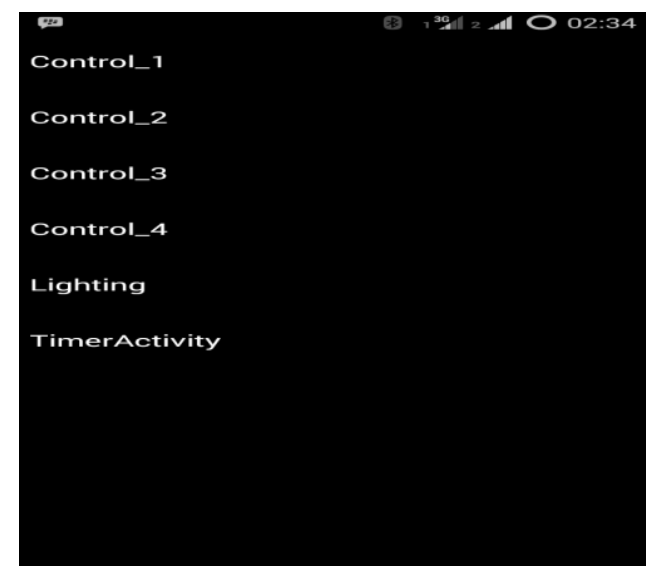

Gambar 9. Tampilan Menu Utama Aplikasi

Keterangan tampilan menu tersebut yaitu sebagai berikut :

Control_1_Input pada aplikasi smartphone untuk mengontrol pin 6 pada Arduino.

Control_2 Input pada aplikasi smartphone untuk mengontrol pin 7 pada Arduino. 
Control_3 Input pada aplikasi smartphone untuk mengontrol pin 8 pada Arduino.

Control_4 Input pada aplikasi smartphone untuk mengontrol pin 9 pada Arduino.

Lighting Input pada aplikasi smartphone untuk mengontrol pin 10 dan 11 pada Arduino. Selain itu terdapat seekbar untuk mengatur PWM

Timer Pilihan untuk mengatur waktu Activity ON maupun OFF sesuai yang diinginkan

3. Tampilan pada menu Control_1

Ketika menyentuh Control_1 maka akan masuk pada tampilan menu, pada tampilan menu akan muncul gambar tampilan sebagai berikut :

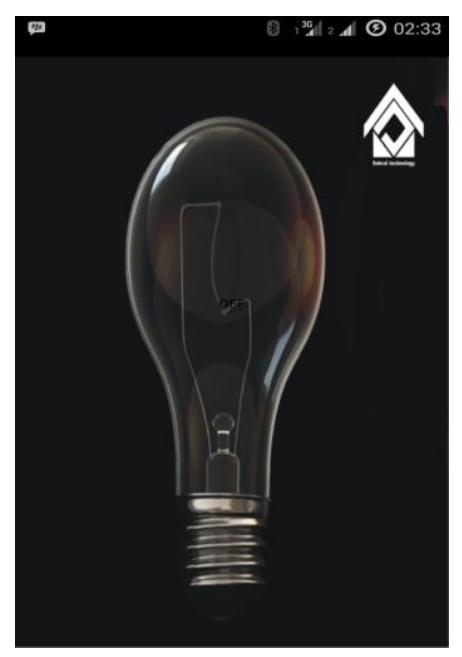

Gambar 10. Tampilan pilihan menu Control_1

Gambar di atas menunjukkan setelah masuk pada menu Control_1, dengan keterangan posisi pengendalian pada posisi OFF. Tampilan tersebut juga terdapat pada menu Control_1, Control_2 dan Control_3. Apabila akan mengendalikan beban atau menghidupkan, maka sentuh tampilan tersebut dan posisi akan berpindah ke posisi ON.

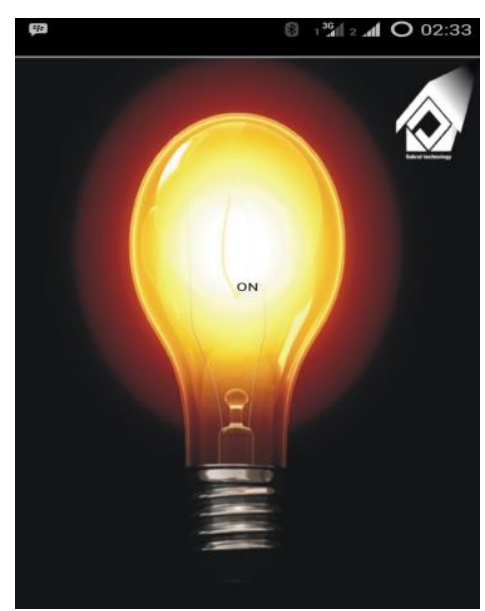

Gambar 11. Tampilan pada posisi ON

\section{Tampilan pada menu Lighting}

Tampilan pada menu lighting berupa seekbar, yang saat pengaturan bisa dilakukan dengan menggeser pada tampilan seekbar yang telah disediakan. Awal masuk menu maka tampilan berupa gambar seperti dibawah ini :

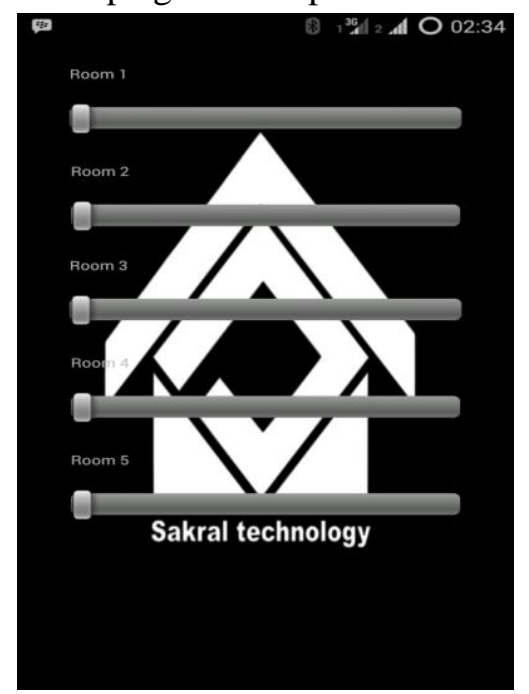

Gambar 12. Tampilan Menu Lighting

Tampilan bisa berjalan dengan baik saat diuji dengan menyentuh seekbar maka posisi akan berubah. 


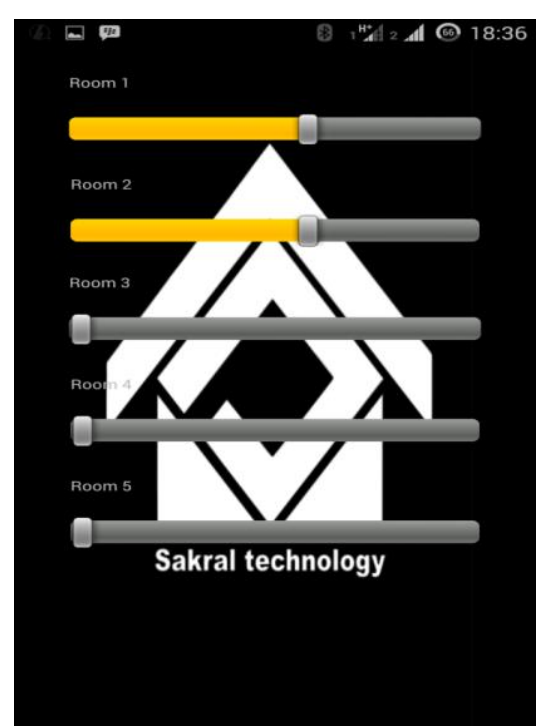

Gambar 13. Tampilan Saat Seekbar dijalankan

5. Tampilan menu Timer Activity

Timer Activity merupakan menu yang digunakan untuk pengaturan waktu ON maupun OFF pada Control_1 sampai Control_4. Pengujian dilakukan dengan menyentuh tampilan dan mengecek seluruh angka dan tombol start maupun stop yang terdapat pada menu.

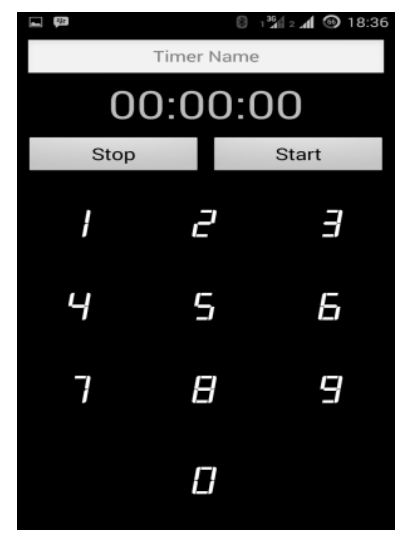

Gambar 14. Tampilan menu Timer Activity

Pada tampilan di atas terdapat angka kemudian Stop dan Start yang sering dijumpai dalam stopwatch di ponsel maupun jam tangan. Pengujian tampilan pada smartphone Android diketahui bahwa tampilan secara keseluruhan dapat berjalan dengan baik sesuai dengan fungsi dan tujuan tampilan.

\section{Pengujian Fungsi Tombol pada Tampilan Aplikasi}

Tahap pengujian kedua yaitu pengujian fungsi dari sistem kendali apakah berfungsi dengan baik saat menyalakan beban lampu, kipas angin maupun lampu LED. Pengujian dengan menguji alat berdasarkan satu Control satu beban sebagai berikut:

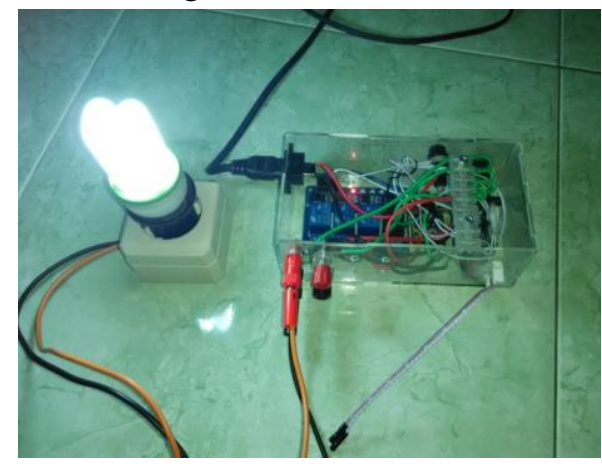

Gambar 15. Pengujian Fungsi Beban AC

Pengujian pada gambar 15 menghasilkan data seperti disajikan pada tabel 1 .

Tabel 1. Pengujian Fungsi Tombol Pengendali Beban AC

\begin{tabular}{c|c|c}
\hline Pengendalian & Beban & Keterangan \\
\hline Control_1 (pin 6) & Lampu 5 W & Nyala \\
\hline Control_2 (pin 7) & Lampu 5 W & Nyala \\
\hline Control_3 (pin 8) & Lampu 5 W & Nyala \\
\hline Control_4 (pin 9) & Lampu 5 W & Nyala \\
\hline
\end{tabular}

Pengujian fungsi dilakukan dengan jarak dekat, sehingga hasil pengujian dari program dan tombol keduanya berfungsi dengan baik. Setelah pengujian tombol Control kemudian menguji menu lighting yang terdapat seekbar didalamnya.

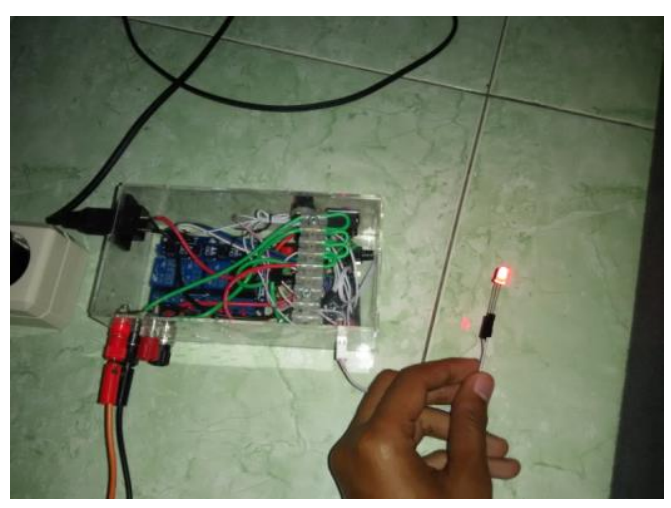

Gambar 16. Pengujian Tombol Seekbar 
Tabel 2. Pengujian Kendali DC Seekbar

\begin{tabular}{c|l|l}
\hline Pengendalian & Beban & \multicolumn{1}{|c}{ Keterangan } \\
\hline Seekbar 1 (pin 10) & $\begin{array}{l}\text { Lampu } \\
\text { led }\end{array}$ & $\begin{array}{l}\text { Nyala bisa diatur } \\
\text { redup terangnya } \\
\text { (PWM) }\end{array}$ \\
\hline Seekbar 2 (pin 11) & $\begin{array}{l}\text { Lampu } \\
\text { led }\end{array}$ & $\begin{array}{l}\text { Nyala bisa diatur } \\
\text { redup terangnya } \\
\text { (PWM) }\end{array}$ \\
\hline
\end{tabular}

Selanjutnya pengambilan data untuk menu Timer activity, hasil pengujian dapat dilihat pada tabel 3 .

Tabel 3. Pengujian Timer

\begin{tabular}{cccc}
\hline $\begin{array}{c}\text { Pengen } \\
\text { dalian }\end{array}$ & Beban & $\begin{array}{c}\text { Timer ON } \\
\text { 20 detik }\end{array}$ & $\begin{array}{c}\text { Timer } \\
\text { OFF 20 } \\
\text { detik }\end{array}$ \\
\hline (pin 6) & Lampu 5 W & Berfungsi & Berfungsi \\
(pin 7) & Lampu 5 W & Berfungsi & Berfungsi \\
(pin 8) & Lampu 5 W & Berfungsi & Berfungsi \\
(pin 9) & Lampu 5 W & Berfungsi & Berfungsi \\
\hline
\end{tabular}

Ketiga pengujian di atas dilakukan untuk mengetahui fungsi dari sistem kendali. Selain itu pengujian dilakukan terhadap koneksi antara bluetooth yang terdapat pada mikrokontroler dengan bluetooth yang terdapat pada smartphone Android.

\section{Pengujian Pengaruh Jarak Terhadap Koneksi Bluetooth}

Adapun pengujian selanjutnya yaitu jarak dan delay waktu bluetooth ketika dilakukan pengendalian dari jarak yang sudah ditentukan.

Tabel 4. Pengujian Pengaruh Jarak Terhadap Waktu Delay

\begin{tabular}{l|l|l|l|l}
\hline Jarak & $\begin{array}{c}\text { Control_ } \\
1\end{array}$ & $\begin{array}{c}\text { Delay } \\
\text { waktu }\end{array}$ & $\begin{array}{c}\text { Seekbar } \\
1\end{array}$ & \multicolumn{1}{|c}{ Delay } \\
\hline $0 \mathrm{M}$ & Nyala & $0 \mathrm{~s}$ & Nyala & $0 \mathrm{~s}$ \\
\hline $2 \mathrm{M}$ & Nyala & $0 \mathrm{~s}$ & Nyala & $0,10 \mathrm{~s}$ \\
\hline $4 \mathrm{M}$ & Nyala & $0 \mathrm{~s}$ & Nyala & $0,22 \mathrm{~s}$ \\
\hline $6 \mathrm{M}$ & Nyala & $0 \mathrm{~s}$ & Nyala & $0,31 \mathrm{~s}$ \\
\hline $8 \mathrm{M}$ & Nyala & $0 \mathrm{~s}$ & Nyala & $0,42 \mathrm{~s}$ \\
\hline $10 \mathrm{M}$ & Nyala & $0 \mathrm{~s}$ & Nyala & $0,49 \mathrm{~s}$ \\
\hline $12 \mathrm{M}$ & Nyala & $0 \mathrm{~s}$ & Nyala & $1 \mathrm{~s}$ \\
\hline $14 \mathrm{M}$ & Nyala & $0 \mathrm{~s}$ & Nyala & $1 \mathrm{~s}$ \\
\hline $16 \mathrm{M}$ & Nyala & $0 \mathrm{~s}$ & Nyala & $1,2 \mathrm{~s}$ \\
\hline $18 \mathrm{M}$ & Nyala & $0 \mathrm{~s}$ & Nyala & $1,32 \mathrm{~s}$ \\
\hline $20 \mathrm{M}$ & Nyala & $0 \mathrm{~s}$ & Nyala & $1,40 \mathrm{~s}$ \\
\hline $22 \mathrm{M}$ & Nyala & $0,2 \mathrm{~s}$ & Nyala & $1,50 \mathrm{~s}$ \\
\hline $24 \mathrm{M}$ & Nyala & $0,5 \mathrm{~s}$ & Nyala & $2,1 \mathrm{~s}$ \\
\hline $26 \mathrm{M}$ & $\begin{array}{l}\text { Tidak } \\
\text { Kyala }\end{array}$ & $\begin{array}{l}\text { Koneksi } \\
\text { putus }\end{array}$ & $\begin{array}{l}\text { Tidak } \\
\text { Nyala }\end{array}$ & $\begin{array}{l}\text { Koneksi } \\
\text { putus }\end{array}$ \\
\hline
\end{tabular}

\section{Analisis Hasil Pengujian}

Analisis ini dilakukan untuk mengetahui tingkat efisiensi penggunaan sistem kendali peralatan listrik dibandingkan dengan penggunaan saklar manual yang biasa sering digunakan. Hasil dari pengujian, menggunakan sistem kendali peralatan listrik lebih hemat waktu dan lebih mudah. Dilihat dari uji jarak dan koneksi bluetooth, kemampuan pengendalian dari jarak jauh maksimal 24 meter masih berfungsi dengan baik. Pengujian dilakukan dengan pengambilan sampel pada Control_1 dan seekbar 1. Ditambah dengan pengaturan timer yang bisa disesuaikan dengan kapan waktu untuk menghidupkan dan mematikan akan lebih menambah tingkat keamanan dari kelalaian pengguna.

\section{Pembahasan}

\section{Tampilan Aplikasi}

Dari hasil pengujian tampilan aplikasi pada smartphone diperoleh hasil tampilan aplikasi berjalan dengan lancar. Pengujian yang dilakukan sesuai dengan langkah percobaan mulai dari awal membuka aplikasi dengan menekan ikon yang kemudian masuk ke menu utama. Saat menu utama muncul terdapat beberapa tulisan untuk masuk ke dalam menu selanjutnya. Tulisan itu antara lain Control_1, Control_2, Control_3, Control_4, Lighting dan Timer Activity. Control_1 sampai dengan Control_4 ketika ditekan akan keluar tampilan berupa gambar lampu.

Tampilan tersebut mewakilkan saklar $\mathrm{ON}$ atau OFF saat alat dijalankan. Untuk menu Lighting ketika ditekan terdapat seekbar yang merupakan pengganti saklar variable atau saklar PWM. Sehingga ketika dijalankan maka pengaturan redup terang ataupun kecepatan motor bisa dilakukan. Akan tetapi pada tampilan ini dikhusukan untuk mengendalikan beban yang bertegangan DC. Sebelum bisa digunakan, software SAKRAL harus disambungkan dengan software aman terlebih dahulu. Proses penyambungannya dijelaskan pada gambar dibawah ini. 
1. Buka software aman yang sudah terinstal pada smartphone

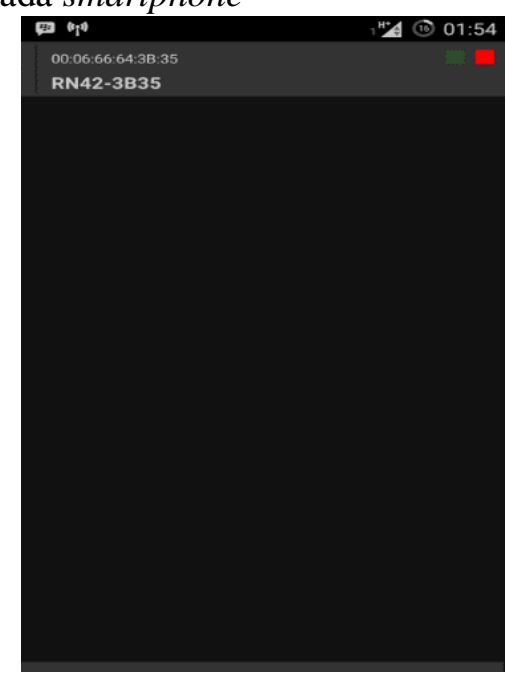

Gambar 17. Software Aman

2. Setelah itu cari dan hubungkan Bluetooth yang akan digunakan dengan menekan nomor serial Bluetooth.

3. Software aman deprogram dengan bluetooth library yang telah tersedia pada android-SDK. Penggunaan software aman sebagai tempat penyimpanan dan menghubungkan device address bluetooth yang telah terkoneksi secara otomatis.

4. Setelah Bluetooth saling menyambung maka buka software SAKRAL.

5. Software SAKRAL diprogram dengan aman library yang dapat terhubung secara otomatis dengan software aman sesaat setelah software SAKRAL dibuka.

Penggunaan modul 4 relay dikarenakan rangkaian tersebut menggunakan optocoupler PC718 yang diparalel dan dipanjar dengan VCC $5 \mathrm{~V}$ pada kaki anoda. Kemudian pada kaki katoda digunakan sebagai pin input yang diberikan logika LOW (ground) untuk mengaktifkan optocoupler PC718. Keluaran dari optocoupler PC718 disambungkan pada transistor NPN sebagai switch pada relay.

\section{Unjuk Kerja Alat}

Kemampuan pengendalian beban dari jarak maksimal 24 meter merupakan kemampuan maksimal dari media komunikasi data. Media yang digunakan untuk mengkomunikasikan data dari smartphone ke mikrokontroler menggunakan bluetooth. Saat pengujian dilakukan dari jarak 0 meter sampai dengan jarak 24 meter, bisa dilihat kemampuan sistem kendali peralatan listrik berfungsi dengan baik. Kendali pada Control_1 sampai Control_4 berfungsi dengan baik ketika diuji dengan rentang jarak 0 meter sampai 24 meter. Sedangkan pengendalian yang berbeban DC ketika diuji didapati keterlambatan waktu 0,10 sampai dengan 2 detik. Hal ini dikarenakan komunikasi data variabel atau yang berubahubah dengan media bluetooth kurang responsive.

\section{SIMPULAN}

Sistem kendali peralatan listrik dibuat berdasarkan perancangan dan pembuatan. Perancangan mulai dari diagram blok, gambar skematik, rancangan hardware dan rancangan software. Perancangan Software berupa pembuatan program pada smartphone Android dan program pada mikrokontroler. Perancangan hardware berupa perakitan komponen dan pembuatan box. Komponen sistem kendali peralatan listrik ini terdiri dari modul relay, arduino promini, bluetooth dan catu daya. Pengujian dilakukan sesuai dengan rencana pengujian dari langkah-langkah pengambilan data.

Setelah alat selesai dibuat dan diuji dapat disimpulkan alat tersebut berfungsi dengan baik sesuai perencanaan. Menu Control_1 sampai dengan Control_4 berfungsi dengan baik. Seekbar dan Timer Activity juga berfungsi dengan baik. Saat pengujian dengan jarak dari jarak 0 sampai 24 meter pada menu seekbar terdapat delay waktu. Selain itu juga sangat efisien karena dapat menghemat waktu untuk pengendalian peralatan listrik dari jarak radius 24 meter.

\section{DAFTAR RUJUKAN}

Dominic Sunnebo. 2013. Android Regain Lead Among U.S Smartphone OS Sales.http://www.kantarworldpanel.co 
m/global/News/Android-Regains-LeadAmong-US-Smartphone-OS-Sales

Gleri Lazardi. 2014. Kebakaran Rumah di Kalibata kibat korsleting listrik. http://www.tribunnews.com/metropolita n/2014/12/08/kebakaran-rumah-dikalibata-akibat korsleting-listrik. Diakses tanggal 12 April 2015

Jazi Eko Istiyanto. 2013. Pemrograman Smartphone Menggunakan SDK Android dan Hacking Android. Yogyakarta : Graha Ilmu

Little Light. 2014. Bagaimana Cara Kerja Bluetooth http://lampukecil.com/2014/08/02/baga imana-cara-kerja-bluetooth/. Diakses tanggal 15 April 2015

Masimmo. 2011. Arduino Pro Mini.

http://arduino.cc/en/Main/ArduinoBoar dProMini

Trevor Lindsey. 2004. Instalasi Listrik Dasar Edisi Ketiga. Jakarta:Erlangga.

Yohan Jati Waloeyo. 2010. Google Android: Sistem Operasi Ponsel Masa Depan. Yogyakarta : CV. Andi Offset 